\title{
Emissions Characteristics of Small Diesel Engine Fuelled by Waste Cooking Oil
}

Amir Khalid ${ }^{1, a}$, M.D. Anuar1, Yusri Ishak ${ }^{1}$, B. Manshoor1, Azwan Sapit ${ }^{1}$, Mutalib Leman² Izzuddin $^{2}$ Zaman $^{2}$

${ }^{1}$ Automotive Research Group (ARG), Centre for Energy and Industrial Environment Studies (CEIES), Universiti Tun Hussein Onn Malaysia, Parit Raja, Batu Pahat, 86400 Johor, Malaysia.

${ }^{2}$ Universiti Tun Hussein Onn Malaysia, Parit Raja, Batu Pahat, 86400 Johor, Malaysia

\begin{abstract}
Biodiesel is an alternative, decomposable and biological-processed fuel that has similar characteristics with mineral diesel which can be used directly into diesel engines. However, biodiesel has oxygenated, more density and viscosity compared to mineral diesel. Despite years of improvement attempts, the key issue in using waste cooking oil-based fuels is oxidation stability, stoichiometric point, bio-fuel composition, antioxidants on the degradation and much oxygen with comparing to diesel gas oil. Thus, the improvement of emission exhausted from diesel engines fueled by biodiesel derived from waste cooking oil (WCO) is urgently required to meet the future stringent emission regulations. The purpose of this research is to investigate the influences of WCO blended fuel and combustion reliability in small engine on the combustion characteristics and exhaust emissions. The engine speed was varied from 1500-2500 rpm and WCO blending ratio from 5-15 vol\% (W5-W15). Increased blends of WCO ratio is found to influences to the combustion process, resulting in decreased the $\mathrm{HC}$ emissions and also other exhaust emission element. The improvement of combustion process is expected to be strongly influenced by oxygenated fuel in biodiesel content.
\end{abstract}

\section{Introduction}

Biodiesel is an alternative fuel that receiving a lot of attention nowadays due to its availability sources and renewability. In Malaysia, Green Technology and Climate Change Council (MTHPI) involved in reducing the $\mathrm{CO} 2$, emissions up to $40 \%$ between 2005 and 2020 . For that reason, the vehicle run by Bio-diesel Fuel (BDF) has been a potential option. Thus, the alternative sources of fuel are receiving a lot attention in the automotive industry. The key issue in using waste cooking oil (WCO) based fuel is oxidation stability, stoichiometric point, biofuel composition, antioxidants on the degradation and much oxygen with comparing to diesel gas oil[1-4]. However, the application of the BDF in the diesel engines offer not only attractive and more economical fuel but also creates problems of higher emissions compared with petroleum based diesel. BDF diesel engines still have problem of emitting NOx and Particulate Matter (PM) into the atmosphere because of the oxidation stability, cetane number, stoichiometric point, bio-fuel composition and antioxidants on the degradation extremely viscous [5-6]. Thus, the improvement of emissions exhausted from BDF engines is urgently required to meet the future stringent emission regulations. It was reported that the implementation of boost pressure, swirl velocity and injection pressure has a great effect on the mixture formation, ignition delay, turbulence, ambient density and ambient pressure, and then affects to the flame propagation, combustion characteristics and emissions production[7-9]. Biodiesel has higher cetane number than

\footnotetext{
aamirk@uthm.edu.my
}

This is an Open Access article distributed under the terms of the Creative Commons Attribution License 2.0, which permits unrestricted use, distribution, and reproduction in any medium, provided the original work is properly cited. 
diesel fuel, no aromatics, almost no sulfur, and contains 10 to $11 \%$ oxygen by weight. These characteristics of the fuel reduce the emissions of carbon monoxide (CO), hydrocarbon (HC), and particulate matter (PM) in the exhaust gas [10]. For that reason, numerous emissions studies using the bio diesel and its blends shows emissions concentration (CO, CO2, HC, PM, NOx as well as deposit) varies depend on source of bio-diesel and engine combustion system. The purpose of this research is to investigate the influences of WCO blended fuel in small engine on the combustion characteristics and exhaust emissions. The engine speed was varied from 1500-2500 rpm without load conditions and WCO blending ratio from 5-15 vol\% (W5-W15).

\section{Experimental Setup}

The biodiesel used was waste cooking oil (WCO) biodiesel which blended form automotive lab and the particular of the tested fuel are detailed in Table 1.The fuel tested were grade II diesel and blends of 5(W5), 10(W10) and $15 \mathrm{vol} \%(\mathrm{~W} 15)$ WCO with the diesel fuel. The grade II diesel designated as standard diesel (Dsl). The kinematic viscosity of WCO blend was measured by Viscolite 700 model VL700-T15. The density properties measured by Metter Toledo Diamond Scale modeled JB703$\mathrm{C} / \mathrm{AF}$. The water content in biodiesel sample is measured by Volumetric KF Tirator model v20. The flash point measured by Pensky-Martens PMA 4. The engine fuel consumption measured by Ono Sokki mass flow meter modeled FM2500

\begin{tabular}{|c|c|c|c|c|c|c|}
\hline \multirow{2}{*}{$\begin{array}{c}\text { Fuel } \\
\text { type }\end{array}$} & $\begin{array}{c}\text { Kensity } \\
\left(\mathrm{g} / \mathrm{cm}^{3}\right)\end{array}$ & $\begin{array}{c}\text { Kinem } \\
\text { atic } \\
\text { viscosi } \\
\text { ty } \\
(\mathrm{Cp})\end{array}$ & $\begin{array}{c}\text { Flash } \\
\text { point } \\
\left({ }^{\circ} \mathrm{C}\right)\end{array}$ & $\begin{array}{c}\text { Water } \\
\text { conten } \\
\mathrm{t}(\%)\end{array}$ & $\begin{array}{c}\text { Acid } \\
\text { value } \\
(\mathrm{mg} \\
\mathrm{KOH} / \mathrm{g})\end{array}$ \\
\hline Ds1 & 0.8394 & 3.0 & 83.0 & 0.050 & 0.423 \\
\hline W5 & 0.8430 & 3.0 & 89.9 & 0.009 & 0.120 \\
\hline W10 & 0.8435 & 3.2 & 102.2 & 0.010 & 0.320 \\
\hline W15 & 0.8456 & 3.2 & 110.0 & 0.013 & 0.480 \\
\hline
\end{tabular}

Table 1. Properties of tested fuels

Figure 1. Blending process of producing biodiesel

Schematic view of blending process is shown in Figure 1. The WCO was blended with Dsl in various concentrations for preparing a biodiesel blend. During blending process, the laboratory scale blending machine was operated at $60^{\circ} \mathrm{C}$ and the mixture was stirred at $70^{\circ} \mathrm{C}$ for 1 hour. The rotating blade speed was adjusted to maintain the same speed at $270 \mathrm{rpm}$.

A schematic view of the emission test and summarizes the engine specification including the operating parameter shown in Fig. 2 and Table 2, respectively. The tested engine that used is small diesel engine, Hatz diesel engine 1B30 with 1 cylinder engine. This engine 1B30 series was design with compact installation dimensions and in all applications with a power requirement up to $8 \mathrm{~kW}$ due to its low weight. The maximum torque is $17.5 \mathrm{Nm}$. For this experiment, the running speeds were simulated at 1500, 2000, and $2500 \mathrm{rpm}$. Measurements data comprised fuel consumption rate $(\mathrm{kg} / \mathrm{hr})$ together with the exhaust emissions like hydrocarbon $(\mathrm{HC})$, oxygen $(\mathrm{O} 2)$, carbon dioxide $(\mathrm{CO} 2)$, carbon monoxide (CO), nitrogen oxides (NOx) and smoke opacity by using autocheck 5 channel gas emission analyzer and dragger MSI. For this research Dsl, W5, W10 and W15 are used for running under similar engine in a manner similar operation conditions. To compare the difference, the measurement 
process was repeated for 3 cycles per each condition. Further analysis and presentation of data is based on the average of measurement.

Table 2. Engine specifications

\begin{tabular}{|l|l|}
\hline \multicolumn{2}{|c|}{ Engine Specification } \\
\hline Model & Hatz Diesel Engine 1B30 \\
\hline Type & Air-cooled four stroke diesel engine \\
\hline Combustion system & Direct injection \\
\hline Number of cylinder & 1 \\
\hline Bore/Stroke & $80 / 69 \mathrm{~mm}$ \\
\hline Displacement & $347 \mathrm{~cm}^{3}$ \\
\hline Sense of rotation on power take-off side & left \\
\hline Engine oil pressure at oil temperature of $100^{\circ} \mathrm{C}$ & $2.5 \mathrm{bar}$ at $3000 \mathrm{rpm}$ \\
\hline Maximum torque & $17 . \mathrm{Nm}$ \\
\hline Weight & $40 \mathrm{~kg}$ \\
\hline
\end{tabular}

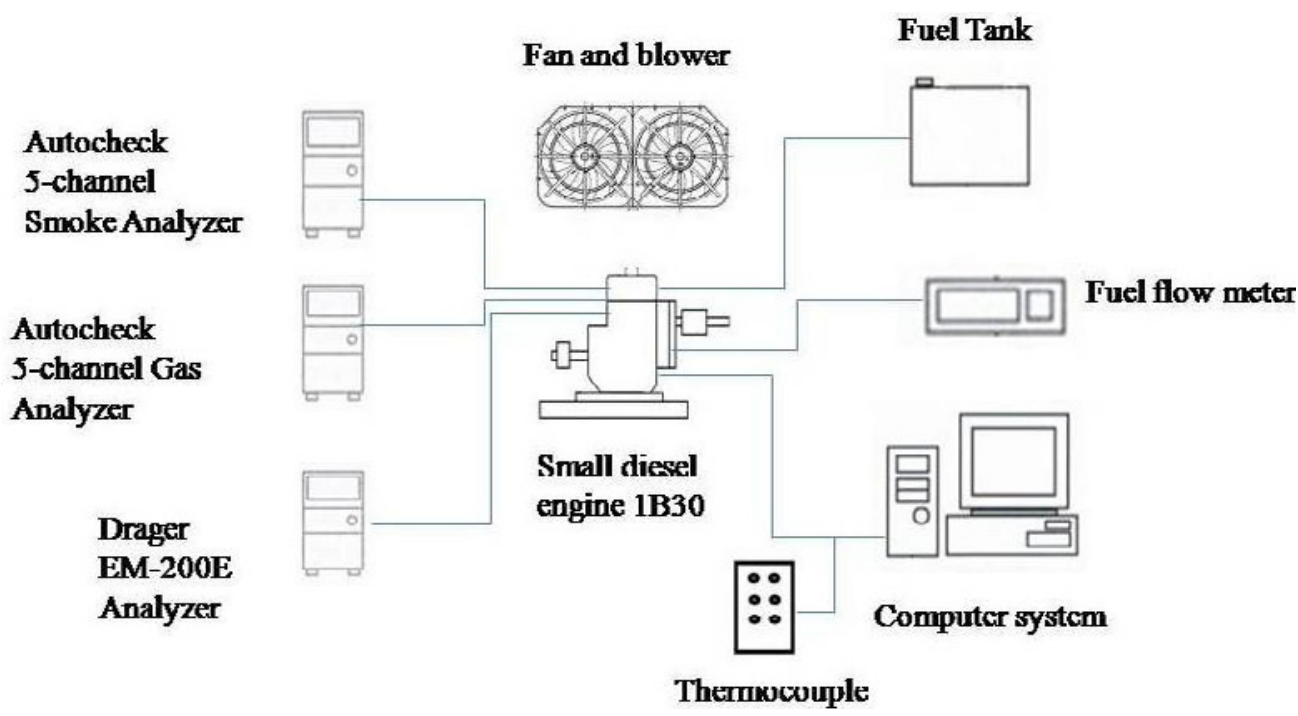

Figure 2. Schematic of Emission test setup

\section{Results and Discussion}

The emission characteristic on different blending ratio and engine speed was shown in Figure 3. The discussion also based on relationship between the emission characteristic of standard diesel (Dsl), W5, $\mathrm{W} 10$ and W15, engine speed of 1500, 2000, and $2500 \mathrm{rpm}$ and simulated the engine run without load condition. As seen in Figure 3, the increasing of blending ratio for all engine speed will influences the decreasing of the $\mathrm{HC}$ and smoke opacity.

These phenomenons happen due to the increasing of blending ratio will weaken the fuel ignitibility and prolong ignition delay as well. In addition this behavior associated with the lower combustion temperature and pressure thus predominantly lower $\mathrm{HC}$ emission and smoke opacity. It is also found that NOx emission is increase inversely proportional with the blending ratio. This may attributed with the low viscosity of fuel due to the higher temperature enhance the fuel-air premixing 
thus influence the higher NOx. It seems that the increasing WCO blending ratio influences the reductions of $\mathrm{CO} 2$ and $\mathrm{CO}$ emissions production.

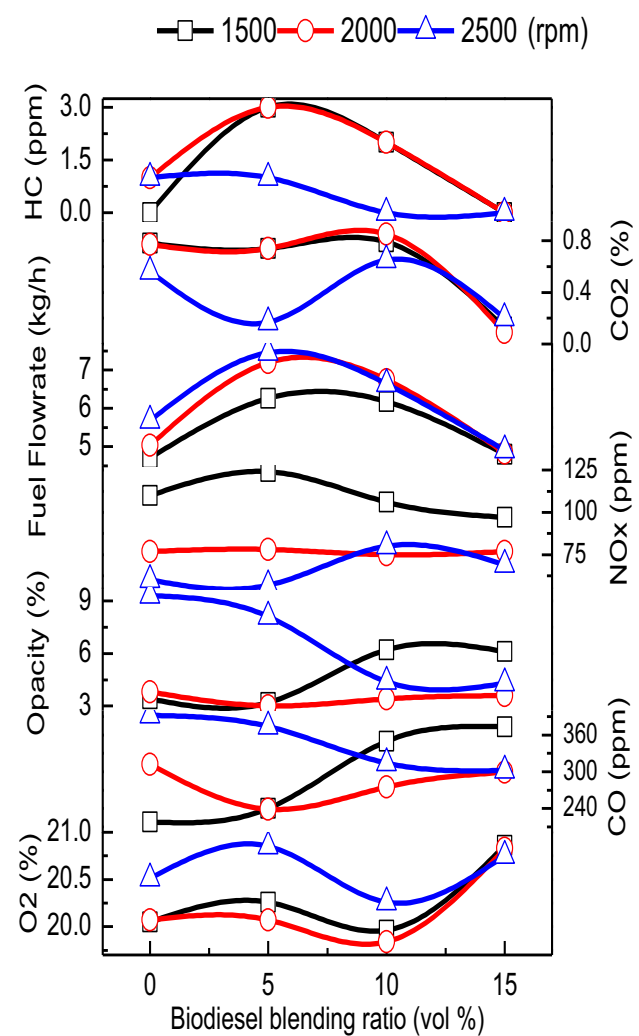

Figure 3. Effects of WCO blending on different engine speed (rpm)

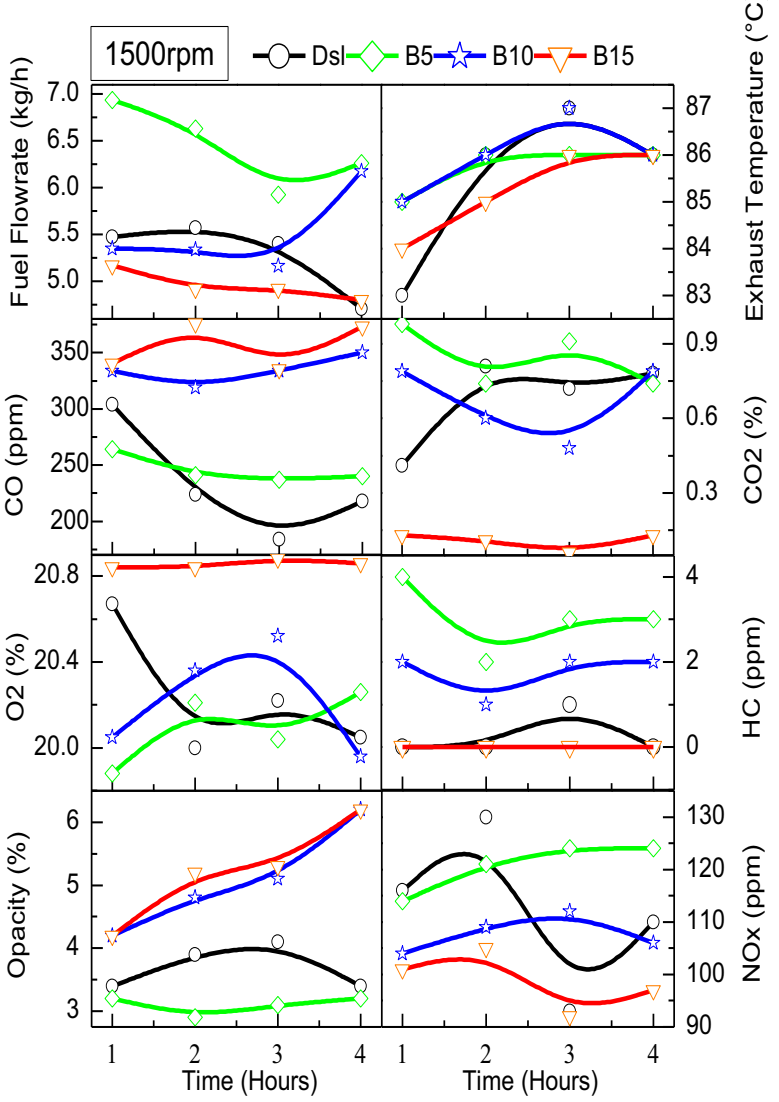

Figure 4. Effects of biodiesel blending with different period of times $(1500 \mathrm{rpm})$ conditions.

Figure 4, 5 and 6 show the emission characteristics effects from W5,W10, W15 and compared with the standard diesel (Dsl) under variant in engine speed and time duration. As seen in Figure 4, 5 and 6, W15 contributes to the lowest $\mathrm{HC}$ emission and $\mathrm{CO} 2$ emissions under all engine speed conditions. The NOx emission starts increasing under 1500rpm of engine speed, but will decreases after 2000rpm and 2500rpm. However, higher blends will result in higher NOx emission such as W5 and W10 during 1500rpm and 2000rpm meanwhile Dsl has the moderate NOx emission among the tested fuels. The B15 shows the lowest at HC, NOx and CO2 emission among other sample biodiesel at all engine speed conditions. On the other hand, the W15 shows the higher value for CO and Smoke Opacity emission at $1500 \mathrm{rpm}$ and $2000 \mathrm{rpm}$ of engine speed. The trend starts decreasing and show the lowest value at $2500 \mathrm{rpm}$ of engine speed. Nevertheless the trend of CO and Smoke Opacity shows the decreasing from $1500 \mathrm{rpm}$ to $2500 \mathrm{rpm}$. On the other hand, the reduction of smoke opacity may attributed to its oxygen content of the injected fuel at high injection pressure, thus more oxygen content will produce more NOx, then decrease the smoke emission indirectly while increase the CO emission when engine speed increases. 


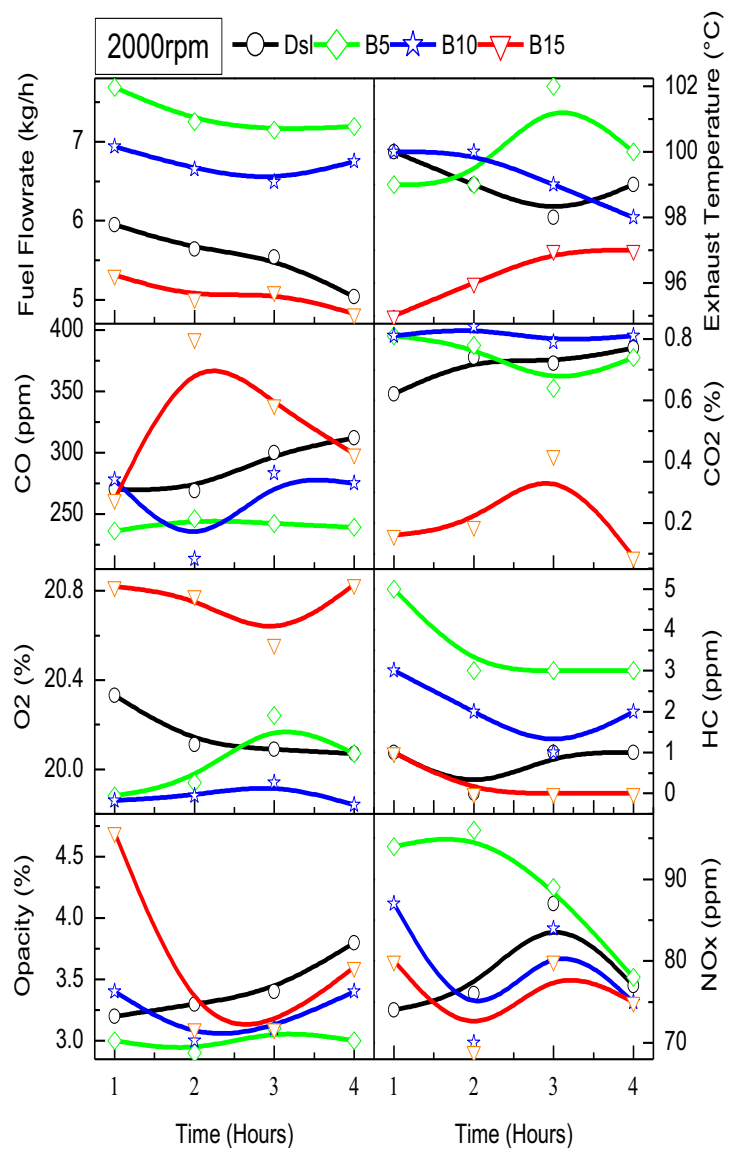

Figure 5. Effects of biodiesel blending with different period of times $(2000 \mathrm{rpm})$

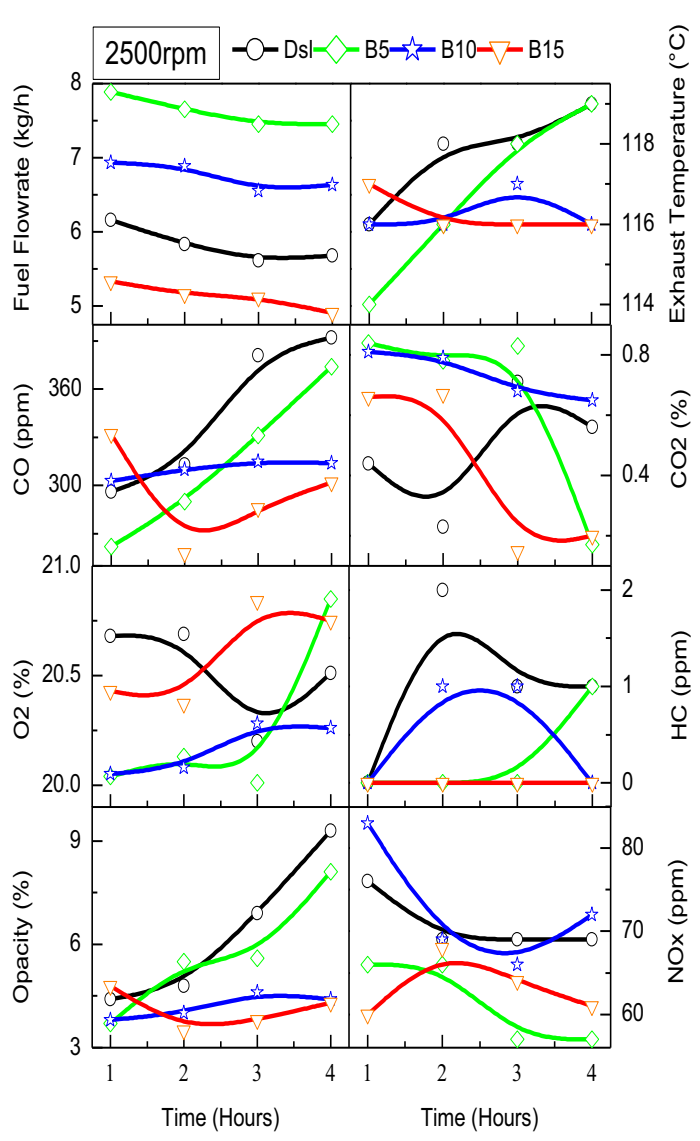

Figure 6. Effects of biodiesel blending with different period of times $(2500 \mathrm{rpm})$

\section{Conclusion}

In this research, the WCO biodiesel with different blending ratio (W5,W10,W15) are obtained in diesel engine and engine speed was adjusted at 1500, 2000, $2500 \mathrm{rpm}$. The summary as follows:

1. The range $\mathrm{W} 5(5 \mathrm{vol} \%)$ to $\mathrm{W} 15(15 \mathrm{vol} \%)$ of blends promotes the reduction of NOx and $\mathrm{CO} 2$ emission due to more oxygen present during combustion, thus the combustion will become more complete and in oxygenated fuel.

2. NOx, Smoke Opacity, $\mathrm{HC}, \mathrm{CO}, \mathrm{CO} 2$ emissions and temperature is lower for high blends of WCO (W15), and decrease as the engine speed increases.

\section{Acknowledgements}

The authors also would like to thank the Ministry of Higher Education, Malaysia for supporting this research under Research Acculturation Grant Scheme (RAGS) Vot. R025, COE-MTUN Grant Scheme Vot.C009 and Fundamental Research Grant Scheme (FRGS) vot.1054.

\section{References}

[1] D. H. Qi, H. Chen, L. M. Geng \& Y. Z. Bian Experimental studies on the combustion characteristics and performance of a direct injection engine fueled with biodiesel/diesel blends. Energy Conversion and Management, 51(12), (2010).

[2] A. Khalid and B. Manshoor, "Analysis of Mixture formation and Flame Development of Diesel Combustion using a Rapid Compression Machine and Optical Visualization Technique", Applied Mechanics and Materials, Trans Tech Publications, Vols. 315, pp 293-298, (2013). 
[3] A. Khalid, "Effect of Ambient Temperature and Oxygen Concentration on Ignition and Combustion Process of Diesel Spray". Asian J. of Scientific Research 6 (3), pp.434-444, (2013).

[4] M. Zhihao, Z. Xiaoyu, D, Junfa, W. Xin, X. Bin., \& W. Jian, Study on Emissions of a DI Diesel Engine Fuelled with Pistacia Chinensis Bunge Seed Biodiesel-Diesel Blends. Procedia Environmental Sciences, 11, 1078-1083. doi:10.1016/j.proenv.2011.12.163, (2011).

[5] W. M. Adaileh, \& K. S. AlQdah, Performance of Diesel Engine Fuelled by a Biodiesel Extracted From A Waste Cocking Oil. Energy Procedia, 18, 1317-1334. doi:10.1016/j.egypro.2012.05.149, (2012).

[6] A. Khalid, S. A. Osman, M. N. M Jaat, N. Mustaffa, S. M. Basharie, B. Manshoor, "Performance and Emissions Characteristics of Diesel Engine Fuelled by Biodiesel Derived from Palm Oil", Applied Mechanics and Materials, Trans Tech Publications, Vols. 315, pp 517-522, (2013).

[7] J. Xue, T.E.G.A.C.H., Effect of biodiesel on engine performances and emissions. Renewable and Sustainable Energy Reviews, pp. 1098-1116, (2010).

[8] M. Canakci, Combustion characteristics of a turbocharged DI compression ignition engine fueled with petroleum diesel fuels and biodiesel. Bioresource Technology, pp. 1167-1175, (2007).

[9] A. Khalid, K. Hayashi, Y. Kidoguchi, T. Yatsufusa, "Effect of Air Entrainment and Oxygen Concentration on Endothermic and Heat Recovery Process of Diesel Ignition",SAE/JSAE International Powertrains, Paper No. 2011-01-1834, Fuels and Lubrications Meeting, (2011).

[10]E. Buyukkaya, Effects of biodiesel on a DI diesel engine performance, emission and combustion characteristics. Fuel, 89(10), 3099-3105, (2010). 